\title{
Effectiveness of Leadership Role in Taking Accountability Measures for School
}

\section{Improvement in Punjab}

* Ishra Batool, PhD Scholar

** Dr. Seema Arif, Associate Professor

*** Muhammad Nadeem, Principal Officer (Corresponding Author)

\begin{abstract}
There is little research on the school principal leadership role for monitoring and evaluating school performance, while Pakistan being the signatory of Sustainable Development Goals, is committed to achieving quality education. Planned changes are undergoing in the governance structures (school accountability) affecting schools in general, particularly school principals. The province of Punjab has excelled in implementing School Reform Roadmap (a whole school improvement program) and conducting a monthly assessment to monitor and evaluate Literacy and Numeracy Drive (LND), an initiative to measure $3^{\text {rd }}$ graders' educational attainment. This research was conducted to review how the leadership role impacts achieving policy-mandated initiatives (LND) for schools' improvement. A case study method was opted for exploring the opinions of school principals from one district of Punjab. A self-constructed questionnaire comprising closed-ended items was used to get opinions from 194 elementary and primary school principals, while were interviewed to get detailed insight into barriers to school improvement and suggestion for better monitoring and evaluation. The case concludes that the participative leadership style is more prevalent among school principals, but the delegative style is more effective for school improvement. Most of the infrastructural facilities are now available in schools, but unfortunately, computer lab and computer teachers are not available in most primary and elementary schools, which is the necessity of LND. The results inform that student attendance is still problematic for schools, and this challenge alone can negatively affect School Sector Reform goals.
\end{abstract}

Keywords: Accountability, Leadership Effectiveness, Literacy, and Numeracy Drive, School Introduction Improvement, School Sector Reform

Education is an essential process of development in any society. Globally, all countries are using their resources to reform the education system (Bifulco, Duncombe \& Yinger, 2005), following the global agenda to improve education quality (Prior, Goldstein \& Leckie, 2020). Pakistan being a signatory of Sustainable Development Goals (SDGs), is also committed to ensuring quality education (Bruns, Macdonald \& Schneider, 2019).

In light of the $18^{\text {th }}$ constitutional amendment and devolution plan, provincial governments were held responsible for developing policies following national education policy. Districts were declared responsible for preparing a detailed work plan to identify the needed action for improvement and devise implementation mechanisms to achieve quality education goals (Halai \& Durrani, 2020). It was claimed that Pakistan faces many problems, especially in infrastructure, provision of basic needs, and lack of supervision and monitoring. All these problems were rendered negatively influencing education quality (Ali, 2014; Dogar, Butt, Butt, \& Qaisar, 2015).

To scrutinize the actions taken on the reform initiatives, the Punjab Government introduced a parallel monitoring system under the Punjab Educational Sector Reform Programme (PESRP) to ensure access, equity, and quality in education (Chaudhary \& Tajwar, 2021). A separate monitoring cell was established in each district chaired by District Monitoring Officer (DMO). DMO works directly under Deputy Commissioner (DC) in close liaison with Programme Monitoring and

* University of Management and Technology, Lahore

** University of Management and Technology, Lahore

*** Mines and Minerals Department Mianwali 
Implementation Unit (PMIU), provincial department. DMOs are not working under the administrative control of EDO-Education, now referred to as Chief Executive Officer, education (CEO-E).

Although PMIU is working under the Secretary of Education's administrative control, field workers of DMO are retired army/air force personnel recruited on a contract basis. Field workers of the DMO office are called Monitoring and Evaluation Assistants (MEA). Each MEA is responsible for visiting at least three schools in a day. MEAs collect data concerning indicators of Roadmap. Afterward, the data is sent to Punjab Information and Technology Board (PITB) through automated software installed on the Punjab Government's tablets to the teachers. A consolidated report of schools is displayed on the website of PMIU daily. Follow-ups are conducted monthly, quarterly, and annually, according to the Roadmap parameters. Each month, the Deputy Commissioner (DC) reviews all District Review Committee (DRC) reports regarding educational activities; PMIU compiles the data with the assistance of PITB monthly. Quarterly the district ranking is published based upon the scores each district had achieved on Roadmap's indicators. A two-month salary is provided as an incentive to DCs and CEO-E of the top five districts; contrarily, a letter of displeasure is posted, and in some cases, severe action is taken against CEO-Es of lower-performing districts.

That is how real-time monitoring of primary and elementary schools is conducted in Punjab. The subject of this study is the Literacy and Numeracy Drive (LND), a performance indicator of the Punjab School Sector Reform Program, to assess teaching and learning at the third-grade level. Issues identified during visits of MEAs are systematically reported to CEO-Es and the related officers in PMIU and PITB. The ultimate authority to take action on the district performance rests with the CEOE; MEAs are the reporting agents; they do not hold a position to resolve the problems. Taking corrective action is the responsibility of CEO-E, who, with the assistance of the Assistant Education Officer (AEO), coordinates with the principal. This way, AEO serves as a liaison manager, also acting as an educational supervisor, mentor, and guide (Wagner, 2020). The CEO-Es are more in a commanding role, while AEOs function in a supportive role. The school heads take a directive role to ensure that the LND targets are met.

It is evident from the above discussion that the school principals exercise the leading role in meeting LND targets; hence, they are the key informants of this study.

\section{Problem Statement}

Elementary education (1-8) is the basic building block in the education of children responsible for laying a strong foundation for student success. School principals are directly responsible for the dayto-day management and school improvement. There is very little research about principals' voice describing their experiences for school improvement and accountability in Pakistan. Qualitative data for mandated accountability shifts for improvement is also missing in the available body of research. Research understudy aimed to highlight the leadership role of elementary school principals for monitoring and evaluation to achieve LND and school improvement targets.

\section{Research Questions}

The following research questions guided the study

1. Which leadership style best serves the mission of whole school improvement?

2. How the leadership role is affecting the achievement of the targets of Literacy and Numeracy Drive (LND) in public elementary schools

3. Why do school principals perceive barriers to school improvement?

\section{Literature Review}

School improvement is a versatile and all-rounded process that demands time not only for implementation but also to understand the leadership role (Khachatryan \& Parkerson, 2020; Verger, Prieto, Pagès \& Villamor, 2020; Ryan, von der Embse, Pendergast, Saeki, Segool, \& Schwing, 2017). According to Awan and Hussain (2020), as different school reform approaches are common, the success of such efforts depends on staff's motivation and capacity building, requiring an effective leadership role. Therefore, school leadership's role for improvement has become a priority agenda globally, and Pakistan is no exception (Arif, Asghar \& Mukhtar, 2020). School principals play an active role in the achievement of school targets through motivation and capacity building of staff on the one hand, and on the other improving the learning environment in the classrooms (Hanushek, 2019; Keddie \& Holloway, 2020; Wöbmann, Lüdemann, Schütz \& West, 2007). Camach and Parham (2019) supported the argument that school leaders provide a bridge between internal school improvement and externally initiated reforms in transforming policy into practice. Principals are 
providing a link between the community, including parents and department/higher authorities. Giving increased autonomy and decision-making at grassroots level school leadership is more critical than ever (Hofflinger \& Hippel, 2020; Lillejord \& Børte, 2020; Paufler \& Sloat, 2020; Dee \& Dizon-Ross, 2019).

Schildkamp (2019) advocates that use of data to drive improvement is also essential in accountability. Allocating resources for data management and analysis is necessary to meet challenges and draw up future improvement strategies. (Narindro, Hardyanto, Raharjo, \& \& Kardoyo, 2020; Arar \& Nasra, 2020; Kelly, Bringe, Aucejo, \& Fruehwirth, 2020). Monitoring and evaluation are key to judging and accelerating improvement as collected data will inform the decision-making process (Paragoso \& Borazon, 2019; Taj, 2019). Countries across the globe have developed monitoring and evaluation systems to provide transparent data, leading to improved quality of management decisions, which results in improvement of whole school performance (Ali, 2020; Oliveira, Moscon, Ferreira \& da Veiga, 2020; Munala \& Ondiek, 2020).

Leadership role requires comprehension of data and its transformation into evidence-based improvement practices since the success of accountability measures depends on evaluating whether or not the opted practices are in-sync with the gathered information and supporting quality improvement efforts (Prior et al., 2020). This complex system of accountability needs a series of feedback loops and information to support continuous improvement. Principals being the custodian of first-hand information and knowing problems at the grassroots level, can do the evaluation job effectively, increasing student achievement, attendance, and educational attainment (Benedict, 2020; Singh, Dwivedi, Kahlon, Sawhney, Alalwan, \& Rana, 2020; Holme, Castro, Germain, Haynes, Sikes, \& Barnes, 2020). In the Pakistani context, Kunwar (2001) propagated that democratic and participative leadership play a significant role in school effectiveness and improvement, while Iqbal (2005) attributed it to the task-oriented and authoritative style. Rehman, Khan and Waheed (2019) had discovered instructional, transformational, and moral styles dominant in a study in Peshawar.

Most theorists of school leadership offer three leadership styles model, authoritarian, democratic, and laissez-faire. This study has used a modified version of leadership styles based on the outcomes of research conducted in the Pakistani context (Amin, Khan, \& Tatlah, 2013; Arif \& Sohail, 2009; Arif et al., 2020; Usman, Iqbal \& Khan, 2016) instead of following Western models blindly. The principal also serves as a liaison between school, community, and higher offices for ensuring implementation of rules \& regulations (Stinchcomb, 2020; Hanushek \& Raymond, 2005; Ibrahim, 2020; Cilliers, Mbiti \& Zeitlin, 2020), which is termed as collaborative leadership style (Hallinger \& Heck, 2011).

\section{Research Design}

This case study aimed to provide an independent examination of a leadership role for achieving targets of Literacy and Numeracy Drive to ensure quality education for school improvement and accountability. District Chakwal, located in the North of Punjab, was chosen as a case for this pilotstudy. According to the census 1998, most of the population resides in rural areas, so it is considered a rural district. As far as the literacy rate of Chakwal is concerned, it was $57 \%$ according to the census 1998. According to the ranking being done based on districts' performances on defined targets of School Reform Roadmap, which started in 2011, it was ranked average or low performing district before 2018. Since 2018 Chakwal has gained a place among the top 5 performing districts of Punjab. Due to this reason, it was selected as a case for this study.

A concurrent mixed-method research design was used to generate insight into school principals' experiences and perspectives on the right learning environment for providing all essential facilities and reflection to highlight the problems and issues they are facing in achieving defined targets. A self-constructed closed-ended survey questionnaire was used to collect data from school principals. Post quantitative data, a structured interview was taken from a proportionate sample of survey participants. One hundred ninety-four school principals filled the survey, out of which 25 were invited for an interview. Twenty principals accepted, and they were interviewed through online web conferencing, including Zoom, Google Meet, and Microsoft team viewers due to COVID 19. Hence, 'rich descriptions' were obtained about the phenomenon accountability of school leaders for school improvement. Among the strengths of this structured interview is the ability to effectively and efficiently collect in-depth information that can provide shared understandings and differing 
perspectives, resulting in a deeper, richer, and more complex understanding of how principals experienced school improvement accountability.

\section{Instrumentation}

In this mixed-methods study, a closed-ended questionnaire was self-constructed in the light of the literature review and LND indicators described in the school Sector Reform Program for the survey. An interview protocol was constructed to conduct in-depth interviews of different stakeholders of school accountability and evaluation, including CEOs, DEO, and Deputy DEO, AEOs (supervisory staff), principals, and teachers. Three questions guided the protocol for finding out the barriers in school improvement and better monitoring of schools for the purpose.

The survey questionnaire has consisted of four parts. $1^{\text {st }}$ part collected demographic information of the participants. Moreover, information about the number of teachers, the number of students, and the number of classrooms was also collected to explore the student-teacher ratio and student classroom ratio. The $2^{\text {nd }}$ part collected data about the availability of basic facilities necessary for creating healthy teaching and learning environment in public schools, such as electricity, clean drinking water, toilets, playground, boundary wall, computer lab, computer teacher, furniture, free textbooks, and a sweeper to ensure the cleanliness of schools. The third part collected information about the achievement of schools on defined indicators of the Punjab School Reform Roadmap. Indicators used are as follows: LND results, teacher presence, student attendance, student retention, cleanliness, fully functioning facilities, and overall school ranking. This data was collected from March 2020-August to, 2020.

In the 4th part, questions items were included to know the leadership styles of school principals and their role to meet the targets of Literacy and Numeracy Drive for school improvement. In the fifth and final part, items were included to know the effectiveness of leadership in accountability and school improvement. Before administering for final data collection, piloting was done to check the reliability of the questionnaire items.

\section{Sampling}

There are 956 elementary and primary schools in district Chakwal. A list of schools was collected from the official website of the School Education Department. A simple random sampling technique was used, and every other school on the list was targeted. The purpose of the research was discussed with Chakwal's CEO (Education), and formal permission for data collection was obtained. The questionnaire was converted to Google Form, and the link was sent to the target samples. Only 194 principals' responses were received that were tabulated on SPSS for further analysis.

Twenty-five principals were selected using a purposive sampling technique for interviews. One-on-one meetings were scheduled after receiving their formal willingness to use web conferencing Apps on Zoom, Google Meet, and Microsoft team viewers as convenient to the participants. Most of them showed their willingness to use Google Meet. Thus desired information was obtained using different settings but the same protocol.

\section{Results}

\section{Descriptive Analysis of the Data}

In this section, a descriptive analysis of the data is discussed, providing details about Part A of the questionnaire. In Table 1 the demographic chc of the sample are pronounced; in Table 2 the facilities provided in schools are described, while in Table 3 the ranking of the school of the district is recounted.

Table 1.

Demographic Information of the Research Participants

\begin{tabular}{|c|c|c|c|c|c|c|}
\hline No. & Variables & $\mathrm{f}$ & $\%$ & $\mathrm{M}$ & Mode & SD \\
\hline & School Type & & & 1.9227 & 2 & .26779 \\
\hline & Urban & 15 & 10 & & & \\
\hline & Rural & 179 & 90 & & & \\
\hline & School Level & & & 1.2268 & 1 & .41985 \\
\hline & Primary & 150 & 76 & & & \\
\hline & Elementary & 44 & 24 & & & \\
\hline & Number of Teachers & & & 1.6753 & 1 & 1.11639 \\
\hline & $2-4$ & 122 & 61 & & & \\
\hline & $5-7$ & 35 & 19 & & & \\
\hline & $8-10$ & 24 & 13 & & & \\
\hline
\end{tabular}




\begin{tabular}{llllll}
\hline \hline $11-13$ & 10 & 5. & & & \\
$<20$ & 3 & 2 & & \\
\hline No of Classrooms & & & 1.6340 & 1 & .93025 \\
$2-4$ & 115 & 59.0 & & & \\
$5-7$ & 45 & 23.0 & & \\
$8-10$ & 28 & 15.0 & & \\
$11-13$ & 4 & 2.0 & & & \\
$<14$ & 2 & 1.0 & & \\
\hline
\end{tabular}

Fig 1 .

Facilities Provided in the Schools of District Chakwal

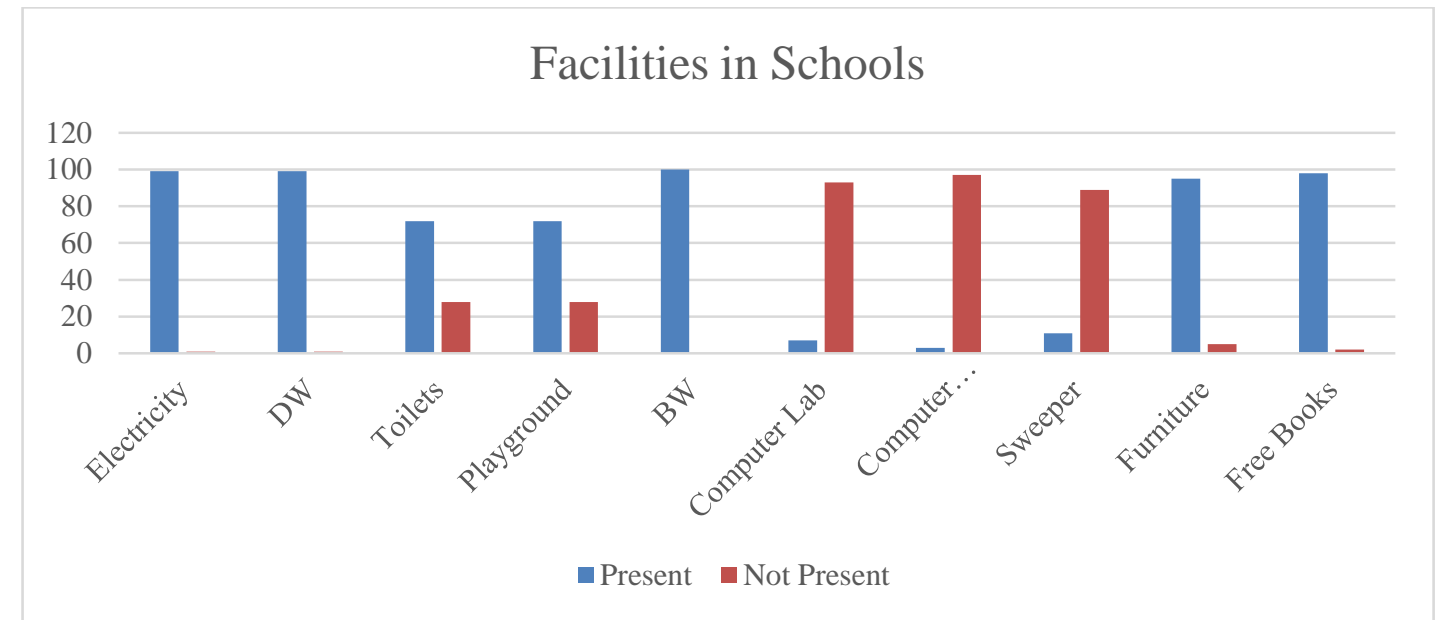

Electricity and drinking water are present in 99\% of schools; Toilets and playgrounds are also available in $72 \%$ of schools. Boundary Wall is present in all schools. A computer lab is available in $7 \%$ of the schools only, while the computer teacher works in $3 \%$ of schools only. Service of a sweeper is available to $1 \%$ of schools, while furniture and free textbooks are available in $95 \%$ and $98 \%$ of the schools, respectively.

Table 2.

School Rankings of District Chakwal according to the indicators of Roadmap April 2019-March 2020

\begin{tabular}{lllll}
\hline & & Ranking & \\
No. & Categories & Good & Average & Poor \\
\hline 1 & LND Result & 93.0 & 7.0 & 0.0 \\
2 & Teacher Presence & 99.0 & 1.0 & 0.0 \\
3 & Student Attendance & 79.0 & 16.0 & 5.0 \\
4 & Cleanliness & 92.0 & 8.0 & 0.0 \\
5 & Functioning Facilities & 96.0 & 4.0 & 0.0 \\
6 & School Ranking & 94.0 & 6.0 & 0.0 \\
\hline
\end{tabular}

LND result of $93 \%$ of schools is good while $7 \%$ of schools are average. The teacher's presence is good in $99 \%$ of schools. Student attendance is ranked well in $79 \%$ of schools; $16 \%$ of schools are ranked average, while $5 \%$ are ranked poor. Regarding the indicator of cleanliness, $92 \%$ of schools are ranked well; similarly, $96 \%$ of schools are ranked good for the full functioning of facilities (electricity, drinking water, toilets, etc.) Overall ranking in all defined indicators, 94\% of schools are ranked well.

\section{Inferential Data Analysis}

In this section, a comprehensive analysis of scale data was performed to answer research questions about the role of leadership in the accountability process. The reliability of the questionnaire was found to be 0.856 for 36 items. Kaiser-Meyer-Olkin Measure of Sampling Adequacy was applied after calculating Cronbach Alpha. The results are mentioned in the table below:

Table 2

KMO and Bartlett's Test for Sampling Adequacy

\begin{tabular}{ll} 
Kaiser-Meyer-Olkin Measure of Sampling Adequacy. & .862 \\
\hline & 3012.011 \\
Bartlett's Test of Sphericity & 630 \\
& .000
\end{tabular}




\section{Exploratory Factor Analysis}

Exploratory factor analysis (EFA) yielded 6 factors. For this purpose Principal Component, Factoring extraction method, and Varimax rotation with Kaiser Normalization were used. EFA, based on the common factor model (Fabrigar, Wegener, MacCallum \& Strahan, 1999), is used when data has many variables to assess (36 in our case). Moreover, there is a strong need to relate them with unobserved or latent variables (Norris \& Lecavalier, 2010). Several well-recognized criteria suggesting reasonable factorability were used for extraction of factors; 1) it was observed that all items to be included in a factor correlation value is 0.3 or more with at least one other item, 2) the KMO is above 0.6 , and 3) and Bartlett's Test of Sphericity is significant. Most of the rotations converged in 3 iterations. The detail of items with their loadings is given in Appendix A. Descriptive detail of six extracted factors is given in Table 3.

Table 3

Scale Statistics

\begin{tabular}{lllllll}
\hline No & Factors & N of Items & Mean & Variance & SD & Alpha \\
\hline 1 & Leadership Style: Delegative & 5 & 19.9742 & 6.264 & 2.50271 & .682 \\
2 & Leadership Style: Commanding & 5 & 19.9175 & 5.858 & 2.42042 & .689 \\
3 & Leadership Style: Participative & 7 & 29.6186 & 10.693 & 3.27003 & .817 \\
4 & Leadership Style: Collaborative & 6 & 29.3505 & 7.908 & 2.81204 &, 739 \\
5 & Leadership Effectiveness & 3 & 12.5052 & 1.609 & 1.26838 & .672 \\
6 & Whole School Improvement & 8 & 33.2887 & 11.916 & 3.45199 & .812 \\
\hline
\end{tabular}

\section{Pearson Product Moment Correlation}

Using the Pearson correlation formula, the relationship between research variables was checked. Correlation results demonstrate that all leadership styles contribute toward effective accountability and school improvement; however, collaborative and participative styles are most significantly and positively related to leadership effectiveness $(r=.612 ; \mathrm{p}<.001)$ and $(r=.531 ; \mathrm{p}<.001)$ respectively. The matrix thus constructed is displayed below:

Table 4

Correlation Matrix Showing Relationship between Leadership Styles, Leadership Effectiveness and Whole School Improvement

\begin{tabular}{lllllll}
\hline Factors & 1 & 2 & 3 & 4 & 5 & 6 \\
\hline Delegative & 1 & $.507^{* *}$ & $.455^{* *}$ & $.388^{* * *}$ & $.411^{* * *}$ & $.571^{* * *}$ \\
Commanding & & 1 & $.571^{* *}$ & $.470^{* * *}$ & $.468^{* * *}$ & $.443^{* * *}$ \\
Participative & & & 1 & $.517^{* *}$ & $.531^{* * *}$ & $.361^{* * *}$ \\
Collaborative & & & & 1 & $.612^{* *}$ & $.598^{* *}$ \\
Leadership Effectiveness & & & & & 1 & $.599^{* * *}$ \\
Whole School improvement & & & & & & 1 \\
\hline
\end{tabular}

Whole School improvement

**. Correlation is significant at the 0.01 level (2-tailed).

\section{Multiple Linear Regression Using Stepwise Method}

After confirmation of significant and positive relationship among all research variables, a multiple linear regression test was applied using the stepwise method to identify the strong predictors of whole school improvement.

Multiple Regression test relates a different story; leadership effectiveness for accountability remains the strongest predictor of whole school improvement $(\beta=.599 ; p<.001)$ (See Model 1 in Table 5, but delegative leadership style may cause more variance in school improvement as compared to any other style $(\beta=.391 ; \mathrm{p}<.001)$ (See Model 2 in Table 5). Moreover, the participative leadership style seems to lose its influence in the presence of delegative and collaborative styles (See Model 4 in Table 5).

Table 5

Multiple Linear Regression Using Stepwise Method

\begin{tabular}{lllllll}
\hline & Model & $\beta$ & $\mathrm{t}$ & Sig. & Tolerance & VIF \\
\hline 1 & (Constant) & & 7.637 & .000 & & \\
& Leadership Effectiveness & .599 & 10.358 & .000 & 1.000 & 1.000 \\
(Constant) & & 5.056 & .000 & & 1.203 \\
& Leadership Effectiveness & .438 & 7.698 & .000 & .831 & 1.203 \\
& Delegative & .391 & 6.878 & .000 & .831 & \\
(Constant) & & 3.000 & .003 & & .590 & 1.695 \\
\hline
\end{tabular}




\begin{tabular}{|c|c|c|c|c|c|c|}
\hline & Delegative & .343 & 6.229 & .000 & .802 & 1.247 \\
\hline & Collaborative & .296 & 4.668 & .000 & .603 & 1.659 \\
\hline \multirow[t]{5}{*}{4} & (Constant) & & 3.453 & .001 & & \\
\hline & Leadership Effectiveness & .319 & 4.870 & .000 & .549 & 1.820 \\
\hline & Delegative & .380 & 6.749 & .000 & .744 & 1.344 \\
\hline & Collaborative & .335 & 5.195 & .000 & .567 & 1.763 \\
\hline & Participative & -.155 & -2.486 & .014 & .612 & 1.635 \\
\hline
\end{tabular}

\section{Thematic Analysis}

This qualitative data analysis was performed on the open-ended questions asked to frame the barriers in the accountability process as perceived by the school principals of Chakwal. This analysis was informed by the view that "coding is a deep reflection about, and, thus, deep analysis and interpretation of the data meanings" (Miles, Huberman, \& Saldana, 2014, p. 72). The interactive nature of data collection and preliminary analysis became a vital part of the process. As a preferred practice, the researchers reviewed open-ended answer notes and engaged in reflective dialogue that generated tentative themes. In second-level coding, pattern codes were developed. Using the descriptive categories and criteria that emerged from the initial data analysis, more detailed pattern codes were created to form the case descriptions.

Building on the findings and emerging themes that resulted from this case study, the crosscase analysis conducted collaboratively by two researchers identified three main themes in assistance with sub-themes. Though this theme development process was ongoing and continuous throughout the study, four distinct stages of analysis included:

1. Commonalities among responses were informally identified to generate a list of possible themes;

2. Following data collection in this case study, one researcher generated a preliminary list of possible themes;

3. Other researchers then had an opportunity to discuss, revise, and develop more fully articulated themes, and

4. Both the researchers reviewed and refined the themes through three drafts.

5. Three broad themes emerged from qualitative data, which are discussed below:

Table 5.

Themes Emerging from the Qualitative Data

\begin{tabular}{|c|c|c|c|}
\hline & $\begin{array}{l}\text { Theme } 1 \\
\text { Administrative Barriers }\end{array}$ & $\begin{array}{l}\text { Theme } 2 \\
\text { Academic Barriers }\end{array}$ & $\begin{array}{l}\text { Theme } 3 \\
\text { Financial Barriers }\end{array}$ \\
\hline \multirow[t]{11}{*}{ Sub-themes } & Pressure of irrelevant task & Lack of professionalism & Low amount of funds \\
\hline & Non-cooperation of parents & $\begin{array}{l}\text { Traditional pedagogical } \\
\text { practices }\end{array}$ & lack of infrastructure \\
\hline & $\begin{array}{l}\text { Pressure of non-academic } \\
\text { activities }\end{array}$ & $\begin{array}{l}\text { Lack of community trust in } \\
\text { public sector schools }\end{array}$ & Provision of labs \\
\hline & Pressure of authorities & $\begin{array}{l}\text { Lack of facilities to adopt } \\
\text { new technology }\end{array}$ & \\
\hline & External pressure & Poor assessment criteria & \\
\hline & $\begin{array}{l}\text { Un-awareness of local needs in } \\
\text { policymaking }\end{array}$ & $\begin{array}{l}\text { Curriculum do not match } \\
\text { with local needs }\end{array}$ & \\
\hline & Non-professional monitoring & $\begin{array}{l}\text { Focus is on quantity, quality } \\
\text { not achieved }\end{array}$ & \\
\hline & Un-realistic monitoring & & \\
\hline & Lack of authority & & \\
\hline & Staff deficiency & & \\
\hline & Fear of punishment & & \\
\hline
\end{tabular}

\section{Discussion}

Most of the schools are facing problems with the shortage of staff as indicated by Khan, Fauzee, and Daud (2014). In most primary schools, there are two teachers only while there are six classes in each primary school. Similarly, schools face problems in infrastructure as most primary schools have two classrooms for six classes. Multigrade teaching is in practice. As far as school facilities and rankings are concerned, most schools are ranked well in performance, and most of the facilities are functioning. 
However, only those indicators are good, which are going to be reflected in Punjab Schools Reform Roadmap (Chaudhary \& Tajwar, 2020)? There are also specific contrasting results. According to data, the target of cleanliness is being achieved but there are no sweepers, there is also a ban for cleanliness to be done by students. Similarly, computer labs are scanty and computer teachers invisible, while the target of LND is achieved which is itself dependent on the availability of modern technology as a test of class three is conducted online on tabs. A similar shortage of resources has been identified in other research (Farooq \& Kai, 2017; Saeed, Ahmad, Salam, Badshah, \& Ali, 2013).

Many leadership styles emerged, namely commanding, delegative, participate, and collaborative during data analysis. The results of the study posit that collaborative and participative styles are most contributing towards school improvement as recommended by the previous research (Kunwar, 2001, Hellinger \& Heck, 2011). Correlation results demonstrate that all leadership styles contribute toward effective accountability and school improvement; however, collaborative, and participative styles are most significantly and positively related to leadership effectiveness. These results are in sync with previous research (Khalil et al., 2016; Arif et al., 2020). However, where leadership effectiveness for accountability remains the strongest predictor of whole-school improvement, delegative leadership has emerged as the second-best predictor of variance in school improvement as compared to other styles. It calls for judicious use of styles according to situational demands (Rehman et al., 2019). Moreover, the participative leadership style seems to lose its influence in the presence of delegative and collaborative styles. In the following section results from in-depth interviews have been discussed.

\section{Administrative Barriers}

Most principals believed that they are indulged in irrelevant works, which creates many school administration problems. They were short of staff and their engagement in non-academic activities like preparation of "daak" (post), keeping the school clean in the absence of a sweeper. Moreover, the local community and parents are also not cooperative in sending their children regularly to schools, especially in rural areas, while principals and teachers are rewarded for low attendance. While Moore, Astor and Benbenishty (2020) also supports that awareness among parents for students' quality education is mandatory. Conwell and Ispa (2020) advocated that the cooperation of parents directly affects the achievement of students. Matthew (2020) supports the research findings that students' absenteeism is a significant hurdle for students' lifelong learning. There is un-realistic monitoring; monitoring authority, especially MEA with no academic background, does not know the real situation, and monitoring carried out by them is not transparent and realistic. Principals having a lack of authority cannot challenge the reports of MEA. All these issues are creating problems.

A principal from a rural school reasoned:

We call parents again and again, but parents do not attend school to listen to us. We cannot find them. We cannot make their names struck off, and we cannot punish them. In this situation, how can we manage it? This problem even becomes severe in crop reaping season. Parents prefer their children to lend a hand on farms to increase their family income.

\section{Academic Barriers}

Some of the principals opined that most of the teachers are adopting a traditional way of teaching. They are also not ready to adopt new pedagogical skills that reflect their non-professional behavior. Salleh (2019) supports the research finding that professional development is a continuous process, and desired results cannot be achieved without teachers' professional development. Moreover, schools also lack facilities according to new demands, especially lack of computer labs and computer teachers' internet connection, which are also a big hurdle in imparting quality education. In most areas, the curriculum does not match local needs, especially in underprivileged areas. Due to the lack of modern facilities, parents with educational backgrounds prefer to send their children to private schools. A school principal related:

We are answerable if the LND result of any student is poor. Instead of that, many questions in the tablet (the instrument used for assessment of students by MEA) are opposite of the actual concept, which is quite enough to confuse any student. Because of all that, teachers cannot improve their students' activities, and students fail or keep scoring low. Because of such policies, teachers are forced to lie to keep themselves in a safe zone to become safe from the punishment for the things he/she is not responsible. 


\section{Financial Barriers}

Few of them believed that funds are not sufficient to run day-by-day activities of the school. Moreover, undue legal formalities are imposed on the expenditure of funds. So many principals remained afraid of using funds. There are two classrooms and one veranda in most primary schools, whereas there are six classes in each primary section. The provision of proper infrastructure is a basic need, but it is a significant problem in the public sector. Multi-grade classrooms and teaching are in practice in most schools that are discouraged internationally for quality education. Gunes (2020) also supports proper classrooms with all necessary equipment to enhance the learning of students. According to Turner (2020), quality education cannot be achieved without the proper provision of infrastructure. One school principal remarked,

They face many problems as there is the very low amount of funds compared to the school's needs. The allocated fund is not distributed within due time. Moreover, there are a lot of complicated legal formalities of paying taxes. Due to the fear of punishment for the wrong operation of funds, we are hesitant to use funds.

\section{Conclusion}

Keeping in view the descriptive analysis it is concluded that many schools lack the necessary resources needed for the effective implementation of LND Drive. Most of the schools are facing problems with the shortage of staff. According to data, the target of cleanliness is being achieved but there are no sweepers, there is also a ban for cleanliness to be done by students? Similarly, computer labs are scanty and computer teachers invisible, while the target of LND is achieved which is itself dependent on the availability of modern technology as a test of class three is conducted online on tabs. Four leadership styles emerged, namely commanding, delegative, participate, and collaborative during factor analysis performed by using exploratory factor analysis. Results thus generated signified that there exists a strong relationship between leadership effectiveness for accountability and whole school improvement. Hence it is concluded that school improvement cannot be achieved relying on anyone's style, there is the need that different styles should be used keeping in view the nature of the assignment.

From thematic analysis where we get aware of the potential barriers faced by school principals challenging their efforts for Whole school improvement, we also realize that school principals are denied opportunities for shared decision making. There are several areas where principals' experiences and practices are beneficial for the formulation and implementation of policies. Their opinions can be much more useful for the transformation of policy into practice. There are more elementary schools due to mandated small class sizes, increasing policymakers' importance and demand.

\section{Future Implications}

Several implications can be drawn related to the study's aim to contribute knowledge about school improvement. The provision of a proper learning atmosphere has too much influence on the achievements of students. Even though the school principals face too many difficulties, including academic, administrative, and financial, they give their best for school improvement. Despite these barriers, school principals of Chakwal are giving their best for whole school improvement and remain at the top in the district rankings. Thus, it is recommended that the focus of the district authorities and Punjab School Education Department should shift from infrastructural development to leadership training and empowerment.

After the review and discussion on the challenges that compromise school improvement and accountability; it is obvious that accountability and improvement run side by side. Therefore, the researchers recommend that sphere of accountability should not be limited to school principals and teachers but all district authorities who are responsible for the administration and governance of schools. It has been observed that school principals use a repertoire of leadership styles to meet the goals of the School Reform Road map; these are commanding, delegative, participative, and collaborative.

We also witness that the scope of leadership practice has widened over time; the school principals seem keener to incorporate participative and collaborative practices in their leadership portfolio, which focus on the involvement of the whole community rather than restricting their influence within the school boundaries. It is strongly recommended that the leadership training now should focus on teaching school leaders to become more flexible in their styles and use different 
practices to their best advantage in meeting goals set for the LND drive in Punjab School Reform Roadmap.

The concept of schooling is changing as our understanding develops of how children learn and concerns much more in which environment they learn best. The impact of the digital age has implications for teaching and learning. Thus LND drive was made a central part of the Punjab Schools Reform Roadmap to introduce both teachers and students to changing demands of the digital age. Following this remarkable initiative, it is advised that schools need to emerge as learning organizations with increased connectivity between students, local and global environments; only then we can realize the goals of the School Reform Roadmap initiated to reach Global Sustainable Development Goals and keep our generations relevant in the times to come. Our key focus is student learning, for which school improvement is mandatory.

The study has suggested the following implications:

- $\quad$ Schools should be equipped according to the need of the $21^{\text {st }}$ century.

- Proper and effective infrastructure should be provided, and school facilities should be improved.

- $\quad$ Particular focus should be paid to the training and capacity building of school principals and supervisory staff.

- $\quad$ School ranking and data should be used for the decision-making process.

- $\quad$ Strategies should be adopted to inculcate the values of commitment, not compliance.

\section{References}

Ali, A. (2020). Impact of Independent Monitoring Unit (IMU) on Public Sector Secondary Schools Performances in Khyber Pakhtunkhwa, Pakistan. Dialogue (Pakistan), 15(1), p.64

Ali, T. (2014). Development of teacher leadership: A multi-faceted approach to bringing about improvements in rural elementary schools in Pakistan. Professional development in education, 40(3), 352-375. Amin, M., Khan, A. M., Tatlah, I. A. (2013). What should a leader do? An investigation of the leader's role to enhance the faculty job satisfaction. Journal of Educational Research, 16(2), 89-106.

Arar, K., \& Nasra, M. A. (2020). Linking school-based management \& school effectiveness: The influence of self-based management, motivation \& effectiveness in the Arab education system in Israel. Educational Management Administration \& Leadership, 48(1), 186-204.

Arif, S. \& Sohail, A. (2009). What works in leading a school? The International Journal of Learning, 16(10), 695-707.

Arif, S., Asghar, Z., \& Mukhtar, S (2020). Interactive effect of school principals' leadership styles \& teacher characteristics on curriculum implementation at public secondary schools of Punjab. UMT Education Review, 3(1), 95-119.

Awan, A. G., \& Hussain, S. F. (2020). The Role of Quality Education in the sustainable development of Pakistan. Global Journal of Management, Social Sciences, \& Humanities, 6(2), 293-319.

Benedict, A. O. (2020). Monitoring \& Evaluation as Catalyst for Sustainable Development in Nigeria. FULafia Journal of Social Sciences, 3(1), 41-48.

Bifulco, R., Duncombe, W., \& Yinger, J. (2005). Does whole-school reform boost student performance? The case of New York City. Journal of Policy Analysis \& Management: The Journal of the Association for Public Policy Analysis \& Management, 24(1), 47-72.

Bruns, B., Macdonald, I. H., \& Schneider, B. R. (2019). The politics of quality reforms \& the challenges for SDGs in education. World Development, 118, 27-38.

Cilliers, J., Mbiti, I. M., \& Zeitlin, A. (2020). Can public rankings improve school performance? Evidence from a nationwide reform in Tanzania. Journal of Human Resources, 0119-9969R1.

Conwell, J. A., \& Ispa-Landa, S. (2020). Principals in Urban Schools under Pressure: Relations with Parents in the Era of Test-Based Accountability. Urban Education, First appeared September 2020.

Oliveira, T. B., Moscon, J. G., Ferreira, E. N. D. N., \& da Veiga, A. B. G. (2020). Prevalence of symptoms of asthma \& allergic rhinitis in children in Southern Brazil: a ten-year monitoring study. Journal of Asthma, 57(4), 373-380.

Dee, T. S., \& Dizon-Ross, E. (2019). School performance, accountability, \& waiver reforms: Evidence from Louisiana. Educational Evaluation \& Policy Analysis, 41(3), 316-349.

Dogar, A. H., Butt, T. M., Butt, I. H., \& Qaisar, S. (2015). Revisiting Pakistan's education system: Addressing the key-flaw. The Dialogue, 10(4), 390-394. 
Farooq, M., S., \& Kai, Y. T., (2017). A review of Pakistan school system. Journal of Education \& Practice, 8(4), 97-101.

Gunes, A. M. (2020). Evaluation of Classroom Management Skills of Primary School Teachers According to the Views of Students \& Teachers. International Online Journal of Educational Sciences, 12(1), 1-17.

Halai A., Durrani N. (2020) School Education System in Pakistan. In P. Sarangapani \& R. Pappu (Eds.). Handbook of Education Systems in South Asia. Global Education Systems. Singapore: Springer. Hallinger P., \& Heck, R.H. (2011). Collaborative leadership \& school improvement: understanding the impact on school capacity \& student learning. In T. Townsend, J. MacBeath (Eds.). International Handbook of Leadership for Learning. Springer International Handbooks of Education, Vol 25. Dordrecht: Springer.

Hanushek, E. A. (2019). Testing, accountability, \& the American economy. The ANNALS of the American Academy of Political \& Social Science, 683(1), 110-128.

Hanushek, E. A., \& Raymond, M. E. (2005). Does school accountability lead to improved student performance? Journal of Policy Analysis \& Management: The Journal of the Association for Public Policy Analysis \& Management, 24(2), 297-327.

Hofflinger, A., \& von Hippel, P. T. (2020). Missing children: how Chilean schools evaded accountability by having low-performing students miss high-stakes tests. Educational Assessment Evaluation \& Accountability, 32, 127-152.

Holme, J. J., Castro, A. J., Germain, E., Haynes, M., Sikes, C. L., \& Barnes, M. (2020). Community Schools as an Urban School Reform Strategy: Examining Partnerships, Governance, \& Sustainability through the Lens of the Full-Service Community Schools Grant Program. Educational Policy, First Published January 30, 2020.

Ibrahim, K. (2020). Monitoring \& Evaluation Of Teacher Effectiveness, A Case Of Teacher Performance Appraisal \& Development Tool In Public Secondary Schools In Nyandarua South Sub-County, Kenya. Advances in Social Sciences Research Journal, 7(1), 320-329.

Keddie, A., \& Holloway, J. (2020). School autonomy, school accountability, \& social justice: stories from two Australian school principals. School Leadership \& Management, 40(4), 288-302.

Kelly, S., Bringe, R., Aucejo, E., \& Fruehwirth, J. (2020). Using global observation protocols to inform research on teaching effectiveness \& school improvement: Strengths \& emerging limitations. Education Policy Analysis Archives, 28 (62), 1-34.

Khachatryan, E., \& Parkerson, E. (2020). Moving teachers to the center of school improvement. Phi Delta Kappan, 101(6), 29-34.

Khan, F., Fauzee, M. S. B. O., \& Daud, Y. (2014a). A cursory review of the importance of teacher training: a case study of Pakistan. Middle-East Journal of Scientific Research, 21(6), 912-917

Lillejord, S., \& Børte, K. (2020). Trapped between accountability \& professional learning? School leaders $\&$ teacher evaluation. Professional development in education, 46(2), 274-291.

Matthew, I. A. (2020). Perception of Teachers on School-Based Factors Influencing Absenteeism of Students in Public Secondary Schools in Central Senatorial District of Ondo State, Nigeria. Asian Journal of Education \& Social Studies, 7(2), 46-55.

Miles, M.B., Huberman, A.M. \& Saldana, J. (2014). Qualitative Data Analysis: A Methods Sourcebook. London: Sage.

Moore, H., Astor, R. A., \& Benbenishty, R. (2020). Role of school-climate in school-based violence among homeless \& nonhomeless students: Individual \& school-level analysis. Child Abuse \& Neglect, 102, 104378.

Munala, E., \& Ondiek, C. O. (2020). Exploring Teacher's Role in ICT Implementation for Learner Progress Monitoring in Secondary Schools in Nairobi County, Kenya. Editon Consortium Journal of Curriculum \& Educational Studies, 2(1), 170-176.

Narindro, L., Hardyanto, W., Raharjo, T. J., \& Kardoyo, K. (2020). Development of accountability for academic performance model based on management information system. VINE Journal of Information \& Knowledge Management Systems, 51(1), 47-63.

Paragoso, S. D., \& Barazon Jr, L. M. (2019). School Monitoring, Evaluation, \& Adjustment (SMEA) in Central Cebu, Philippines. CNU Journal of Higher Education, 13(1), 36-75.

Paufler, N. A., \& Sloat, E. F. (2020). Using standards to evaluate accountability policy in context: School administrator \& teacher perceptions of a teacher evaluation system. Studies in Educational Evaluation, 64, 1-15. 
Prior, L., Goldstein, H., \& Leckie, G. (2020). School value-added models for multivariate academic \& non-academic outcomes: A more rounded approach to using student data to inform school accountability. Available at:https://arxiv.org/abs/2001.01996.

Ryan, S., von der Embse, N., Pendergast, L. L., Saeki, E., Segool, N., \& Schwing, S. (2017). Leaving the teaching profession: The role of teacher stress \& educational accountability policies on turnover intent. Teaching \& Teacher Education, 66, 1-11.

Saeed, M., Ahmad, I., Salam, M., Badshah, R. \& Ali, S. (2013). Critical Analysis of Problems of School Teachers in Pakistan: Challenges \& Possible Solutions. Journal of Education \& Practice, 4(4), 169-175.

Salleh, M. J. (2019). Best practices for promoting teachers' professional development in Malaysia. UMT Education Review, 2(2), 01-26.

Schildkamp, K. (2019). Data-based decision-making for school improvement: Research insights \& gaps. Educational Research, 61(3), 257-273.

Singh, P., Dwivedi, Y. K., Kahlon, K. S., Sawhney, R. S., Alalwan, A. A., \& Rana, N. P. (2020). Smart monitoring \& controlling of government policies using social media \& cloud computing. Information Systems Frontiers, 22(2), 315-337.

Stinchcomb, D. (2020). The Potential Link between Teacher Evaluation \& Student Achievement (Doctoral dissertation, Seton Hall University).

Taj, T. (2019). The impact of monitoring \& evaluation system on teachers' absenteeism. International Journal of Research in Social Sciences, 9(5), 764-781.

Turner, J. (2020). The beginning of an infrastructure of failure in academia. Emotion, Space \& Society, 35, 100647. Rehman, A. U., Khan, M. I. \& Waheed, Z., (2019). School heads' perceptions about their leadership styles: A qualitative study. Journal of Education \& Educational Development, 6(1), 138-153.

Usman, K., Iqbal, J., \& Khan, A. (2016). Exploring leadership styles of school administrators in Pakistan. FWU Journal of Social Sciences, 10(1), 39-47.

Verger, A., Prieto, M., Pagès, M., \& Villamor, P. (2020). Common standards, different stakes: A comparative \& multi-scalar analysis of accountability reforms in the Spanish education context. European Educational Research Journal, 19(2), 142-164.

Wagner, I. (2020). Effectiveness \& perceived usefulness of follow-up classroom observations after school inspections in Northern Germany. Studies in Educational Evaluation, 67, 100913.

Wöbmann, L., Lüdemann, E., Schütz, G., \& West, M. R. (2007). School accountability, autonomy, choice, \& the level of student achievement: International evidence from PISA 2003. OECD Education Working Papers, No. 13. Paris: OECD Publishing 